\title{
Estimation of sediments produced in a subbasin using the Normalized Difference Vegetation Index
}

\author{
Estimativa dos sedimentos produzidos em uma sub-bacia usando o \\ índice de vegetação por diferença normalizada
}

\author{
Guilherme Henrique Expedito Lense ${ }^{1 *}(\mathbb{D})$, Rodrigo Santos Moreira' ${ }^{1}$, Fernanda Almeida Bócoli² (D), \\ Junior Cesar Avanzi ${ }^{2}$ D, Alexandre Elias de Miranda Teodoro' ${ }^{1}$ (D), Ronaldo Luiz Mincato' ${ }^{10}$
}

\author{
${ }^{1}$ Universidade Federal de Alfenas/UNIFAL, Alfenas, MG, Brasil \\ 2Universidade Federal de Lavras/UFLA, Lavras, MG, Brasil \\ ${ }^{*}$ Corresponding author: guilhermeelense@gmail.com \\ Received in December 20, 2019 and approved in May 12, 2020
}

\begin{abstract}
Among the parameters considered by the Revised Universal Soil Loss Equation (RUSLE), the soil cover and management factor (C) is the main human influenced factor affecting the estimation of water erosion, and one of the most sensitive to spatiotemporal variations. Consequently, this study aims to compare the efficiency of $C$ factor estimates obtained from the literature for each land-use class $\left(C_{i j}\right)$ and by calculation based on the Normalized Difference Vegetation Index $\left(\mathrm{C}_{\mathrm{NDV}}\right)$. We test the hypothesis that soil loss estimates based on $\mathrm{C}_{\mathrm{NDVI}}$ approach are more accurate than those based on $C_{\text {lit }}$. Water erosion was estimated based on soil morphological, physical, and chemical properties in addition to climate, relief, management practices, and land use and cover. The modeling steps were realized with the help of the Geographic Information System. The results were validated using the data of total sediment transported with water discharge and daily runoff. RUSLE underestimated soil losses by $0.64 \mathrm{Mg} \mathrm{ha}^{-1}$ year ${ }^{-1}$ using $\mathrm{C}_{\mathrm{lit}}$ and $0.45 \mathrm{Mg} \mathrm{ha}^{-1}$ year-1 with $\mathrm{C}_{\mathrm{NDVl}}$, which corresponds to errors of $21.05 \%$ and $14.80 \%$, respectively. Therefore, the $C_{\text {NDVI }}$ factor results are more accurate. Both methodologies identified areas with high erosion rates where the adoption of mitigation measures should be prioritized.
\end{abstract}

Index terms: Soil conservation; water erosion; modeling; RUSLE.

\begin{abstract}
RESUMO
Dentre os parâmetros considerados pela Equação Universal de Perda de Solo Revisada (RUSLE) a cobertura e manejo do solo (C) é o principal fator de influência humana na estimativa da erosão hídrica, e um dos mais sensíveis a variações espaço - temporais. Consequentemente, este estudo tem como objetivo comparar a eficiência das estimativas do fator $C$ obtidas na literatura para cada classe de uso da terra ( $C_{\text {lit }}$ ) e por cálculo com base no Índice de Vegetação por Diferença Normalizada $\left(C_{N D v}\right)$. Testamos a hipótese de que as estimativas de perda de solo com base na abordagem $C_{N D v l}$ são mais precisas do que aquelas baseadas no $C_{\text {lit. }}$ A erosão hídrica foi estimada com base nas propriedades morfológicas, físicas e químicas do solo, além de clima, relevo, práticas de manejo e uso e cobertura da terra. As etapas da modelagem foram realizadas com a ajuda do Sistema de Informações Geográficas. Os resultados foram validados utilizando os dados do sedimento total transportado com descarga de água e escoamento diário. RUSLE subestimou as perdas do solo em $0,64 \mathrm{Mg}^{-1}$ ano-1 usando $\mathrm{C}_{\text {lit }}$ e $0,45 \mathrm{Mg} \mathrm{ha}^{-1}$ ano $^{-1}$ com $\mathrm{C}_{\mathrm{NDV}}$, o que corresponde aos respectivos erros de 21,05\% e 14,80\%. Portanto, os resultados do fator $\mathrm{C}_{\mathrm{NDVl}}$ são mais precisos. Ambas as metodologias identificaram áreas com altas taxas de erosão, onde a adoção de medidas mitigadoras deve ser priorizada.
\end{abstract}

Termos para indexação: Conservação do solo; erosão hídrica; modelagem; RUSLE.

\section{INTRODUCTION}

Uncontrolled water erosion is the main reason for soil degradation in tropical regions, with the potential to make large areas economically unproductive. The erosion process not only causes soil losses but also leads to many secondary environmental problems such as flooding, siltation, and water body pollution
(Beskow et al., 2009; Prasannakumar et al., 2012; Sun et al., 2014).

A quantitative assessment of erosion is required to understand the range and magnitude of the process to determine effective mitigation strategies. However, measuring erosion rates is a complex task, particularly in rural areas of developing countries, due to the high cost 
of analyses and the long period required to detect trends (Prasannakumar et al., 2012; Anh et al., 2014).

Moreover, soil loss quantification methods based on experimental plots have many limitations in terms of the representativeness and reliability of the results. Such methodologies cannot provide the spatial distribution of soil loss, and their application is often possible only in small areas (Chen et al., 2011). The use of water erosion modeling overcomes the limitations of direct measurement methods and allows the estimation of soil losses with a satisfactory level of accuracy. Moreover, these models are useful tools to increase our understanding of environmental processes and assist in decision-making (Panagos; Katsoyiannis, 2019).

The Revised Universal Soil Loss Equation (RUSLE) is the most widely used in the world model and is relatively simple to apply with low data requirements (Prasannakumar et al., 2012; Ganasri; Ramesh, 2016). The association of RUSLE with Geographic Information System (GIS) and remote sensing allows the assessment of spatial distribution of soil losses and the identification of areas with the most intense erosion rates (Cunha; Bacani; Panachuki, 2017; Imamoglu; Dengiz, 2017; Haidara et al., 2019).

RUSLE estimates annual average soil loss as a function of rainfall erosivity (R), soil erodibility (K), topographic factor (LS), soil cover and management factor $(\mathrm{C})$, and conservation practices factor $(\mathrm{P})$ (Renard et al., 1997). The $\mathrm{C}$ factor represents the protective effect of vegetation against the impact of rainfall on soil and is the main factor controlling anthropic erosion (Ouyang et al., 2010; Devátý et al., 2019). In addition, the $\mathrm{C}$ factor is one of the most sensitive parameters to spatiotemporal variations when it is influenced by vegetation growth and rainfall dynamics (Nearing et al., 2005).

Traditionally, the $\mathrm{C}$ factor is determined from a constant value found in the literature, which was obtained from experimental plots developed for different regions of a study area. This methodology cannot represent the spatial heterogeneity of soil vegetation cover (Almagro et al., 2019). To improve soil loss estimation, Durigon et al. (2014) developed an equation using the Normalized Differences Vegetation Index (NDVI) to determine the C factor.

In southeastern Brazil, several authors estimated soil losses using RUSLE based on C factor values obtained in the literature (Beskow et al., 2009; Oliveira et al., 2014; Mendes Júnior et al., 2018; Tavares et al., 2019), and there were a few NDVI-based approaches (Durigon et al., 2014; Silva et al., 2017). This study aims to compare the efficiency of the $\mathrm{C}$ factor estimation based on values obtained from the literature for each land-use class $\left(\mathrm{C}_{\mathrm{lit}}\right)$ and the $\mathrm{C}$ factor calculation based on NDVI $\left(\mathrm{C}_{\mathrm{NDVI}}\right)$. We test the hypothesis that the results of the soil loss estimates based on the $\mathrm{C}_{\mathrm{NDVI}}$ approach are more accurate than those based on the $\mathrm{C}_{\text {lit }}$.

\section{MATERIAL AND METHODS}

\section{Study area}

The research was carried out in the Coroado Stream subbasin, which belongs to the Rio Grande River basin. The area is in the municipality of Alfenas, Minas Gerais State, southeastern Brazil. According to Köppen, the climate is classified as mesothermal tropical $(\mathrm{Cwb})$ with a mean annual rainfall of $1500 \mathrm{~mm}$ and a mean temperature of $22{ }^{\circ} \mathrm{C}$ (Alvares et al., 2013; Instituto Nacional de Meteorologia - INMET, 2019).

The study area is 559.5 ha with altitudes ranging from 795 to $922 \mathrm{~m}$, predominantly undulating relief, and an average slope of $13.54 \%$. The slope map (Figure 1B) was constructed using the ArcMap 10.3 Slope tool (Environmental Systems Research Institute - Inc. - ESRI, 2015) from the Digital Elevation Model (DEM, Figure 1A) extracted from the Minas Gerais state contour lines (Infraestrutura de Dados Espaciais do Sistema Estadual de Meio Ambiente e Recursos Hídricos - SISEMA, 2019).

The soil was classified as Dystrophic Red Latosol (LVd), and the subbasin is occupied by coffee $(36.45 \%)$, native and regenerating forest $(34.85 \%)$, maize $(11.71 \%)$, sugarcane $(6.12 \%)$, eucalyptus $(2.70 \%)$, access roads $(3.27 \%)$, facilities $(1.77 \%)$, and drainage $(3.13 \%)$. The land use map (Figure 1C) was prepared using Landsat-8 Operational Land Imager (OLI) satellite imagery, which was obtained from Imaging Division (Instituto Nacional de Pesquisas Espaciais - INPE, 2019), using bands 2, 3, and 4 , orbit/point 219/75. Images taken between July 2018 and June 2019 were selected for the map, and image handling was performed in ArcMap 10.3 (ESRI, 2015).

\section{Revised Universal Soil Loss Equation (RUSLE)}

The RUSLE model is expressed according to Equation 1 (Renard et al., 1997) as follows:

$A=R \cdot K \cdot L S \cdot C \cdot P$

where $\mathrm{A}$ is the average annual soil loss in $\mathrm{Mg} \mathrm{ha}^{-1}$ year-1, $\mathrm{R}$ is the rainfall erosivity factor in $\mathrm{MJ} \mathrm{mm} \mathrm{ha}^{-1} \mathrm{~h}^{-1}$ year ${ }^{-1}, \mathrm{~K}$ is the soil erodibility factor in $\mathrm{Mg} \mathrm{h} \mathrm{MJ}^{-1} \mathrm{~mm}^{-1}$, LS is the dimensionless topographic factor (given by the relationship between the length (L) and inclination of the relief (S)), C is the dimensionless cover and management factor, and $\mathrm{P}$ is the dimensionless conservation practices factor. 

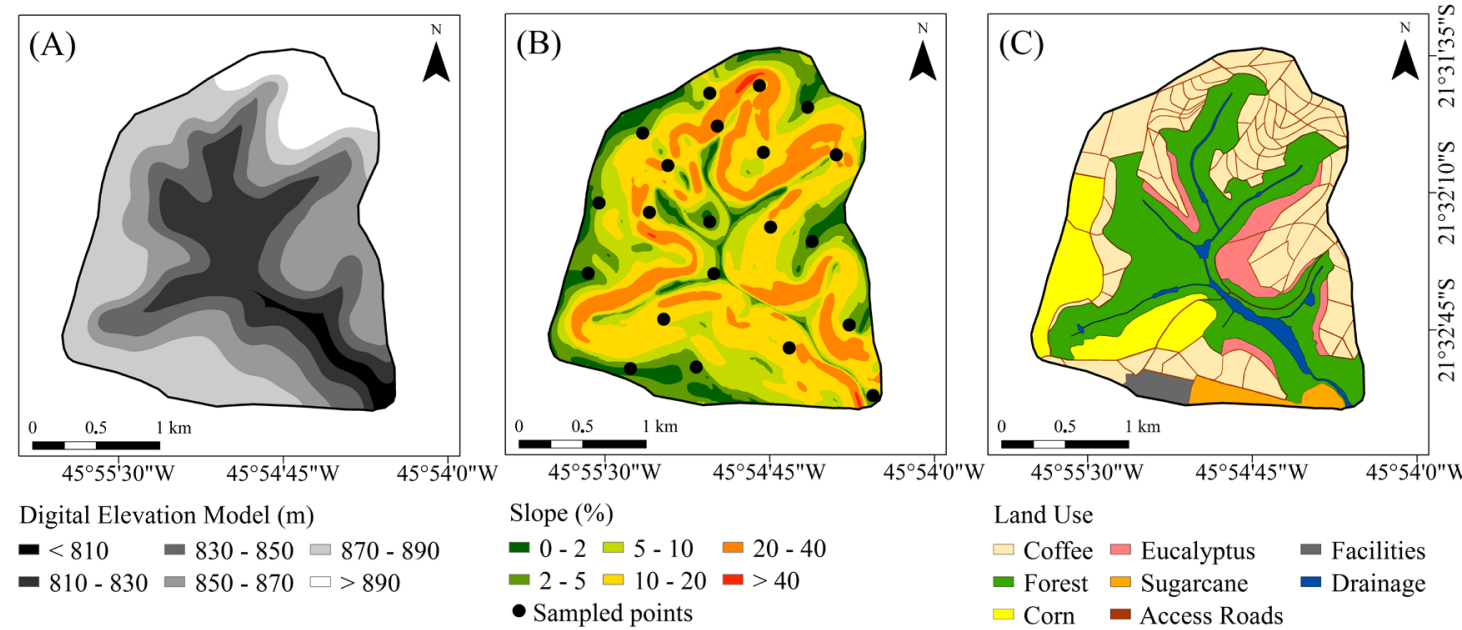

Figure 1: Digital Elevation Model (A) Slope map with soil sampling locations (B) and Land use map (C) of the Coroado Stream subbasin, Alfenas, Minas Gerais, Brazil.

The $\mathrm{R}$ factor reflects the effect of rainfall intensity on soil erosion, and its value is determined as a function of continuous rainfall data (Wischmeier; Smith, 1978). Due to the lack of precipitation data, the $\mathrm{R}$ factor was determined according to the multivariate geographic model for southeastern Brazil proposed by Mello et al. (2013) (Equation 2). The calculation was performed for each cell of the DEM (Figure 1A) using the ArcMap 10.3 Raster Calculator tool (ESRI, 2015).

$R=-399433+420.49 \cdot A-78296 \cdot L A-0.01784 \cdot A^{2}$

$-1594.04 \cdot L A^{2}+195.84 \cdot L O^{2}+17.77 \cdot L O \cdot A$

$-1716.27 \cdot L A \cdot L O+0.1851 \cdot L O^{2} \cdot A+0.00001002$.

$L O \cdot A^{2}+0.01364 \cdot L A^{2}+0.01364 \cdot L A^{2} \cdot L O^{3}$

where $\mathrm{A}$ is the altitude in meters, LA is the latitude, and LO is the longitude. Both LA and LO are in negative decimal degrees.

The $\mathrm{K}$ factor represents the susceptibility of the soil to erosion (Renard et al., 1997) and was determined from the physical and chemical attributes of the soil according to the indirect method of Silva et al. (1999) (Equation 3).

$$
\begin{aligned}
& K=0.0477-0.00966 \cdot X_{14}+0.0163 \cdot X_{16} \\
& -0.0112 \cdot X_{17}+0.0185 \cdot X_{18}-0.0151 \cdot X_{19} \\
& -0.000246 \cdot X_{22}-0.000358 \cdot X_{23}+0.000147 \cdot X_{24} \\
& -0.000143 \cdot X_{25}+0.00326 \cdot X_{26}-0.00126 \cdot X_{27} \\
& -0.000229 \cdot X_{31}+0.000107 \cdot X_{32}+0.000269 \cdot X_{34}
\end{aligned}
$$

where, $X_{14}$ is the code of the hue of the moist soil according to Munsell (dimensionless), $X_{16}$ is the structure degree code (dimensionless), $X_{17}$ is the structure size code (dimensionless), $\mathrm{X}_{18}$ is the structure shape code (dimensionless), $\mathrm{X}_{19}$ is the soil plasticity code (dimensionless), $X_{22}$ is the fine sand content dispersed in $0.1 \mathrm{~mol} \mathrm{~L}^{-1} \mathrm{NaOH}\left(\mathrm{g} \mathrm{kg}^{-1}\right), \mathrm{X}_{23}$ is the very fine sand content dispersed in $0.1 \mathrm{~mol} \mathrm{~L}^{-1} \mathrm{NaOH}$ $\left(\mathrm{g} \mathrm{kg}^{-1}\right), \mathrm{X}_{24}$ is the silt content dispersed in $0.1 \mathrm{~mol}$ $\mathrm{L}^{-1} \mathrm{NaOH}\left(\mathrm{g} \mathrm{kg}^{-1}\right), \mathrm{X}_{25}$ is the clay content dispersed in $0.1 \mathrm{~mol} \mathrm{~L}^{-1} \mathrm{NaOH}\left(\mathrm{g} \mathrm{kg}^{-1}\right), \mathrm{X}_{26}$ is the very coarse sand content dispersed in water $\left(\mathrm{g} \mathrm{kg}^{-1}\right), \mathrm{X}_{27}$ is the coarse sand content dispersed in water $\left(\mathrm{g} \mathrm{kg}^{-1}\right), \mathrm{X}_{31}$ is the silt content dispersed in water $\left(\mathrm{g} \mathrm{kg}^{-1}\right), \mathrm{X}_{32}$ is the clay content dispersed in water $\left(\mathrm{g} \mathrm{kg}^{-1}\right)$, and $\mathrm{X}_{34}$ is the flocculation index (dimensionless).

The $\mathrm{K}$ factor parameters were determined using soil samples collected in January 2019 at 18 points distributed in the subbasin area (Figure 1B). Disturbed and undisturbed soil samples were collected from the surface $(0-20 \mathrm{~cm})$ and subsurface $(20-40 \mathrm{~cm})$ layers using a probe and a cylinder sampler $\left(92.53 \mathrm{~cm}^{3}\right)$, respectively. The soil particle size distribution was determined by the pipette method, with and without $0.1 \mathrm{~mol} \mathrm{~L}^{-1} \mathrm{NaOH}$ (Gee; Bauder, 1986) and the flocculation index according to Empresa Brasileira de Pesquisa Agropecuária - Embrapa (2017).

The LS factor was calculated based on the DEM (Figure 1A) using Equation 4, proposed by Moore and Burch (1986) as follows: 
$L S=\left(\frac{F A \cdot 10}{22.13}\right)^{0.4} \cdot\left(\frac{\sin (S)}{0.0896}\right)^{1.3}$

where FA is the flow accumulation expressed as the DEM grid cell number, $\mathrm{S}$ is the declivity of the subbasin in degrees, and the spatial resolution of the DEM is $10 \mathrm{~m}$.

The $\mathrm{C}$ factor comprises the effects of vegetation cover on soil loss and ranges from 0 (high vegetation cover) to 1 (bare soil) (Oliveira et al., 2014). We calculated the $\mathrm{C}$ factor using two approaches: based on the values presented in the literature for each subbasin land-use class $\left(\mathrm{C}_{\text {lit }}\right)$ and based on NDVI $\left(\mathrm{C}_{\mathrm{NDVI}}\right)$ according to the methodology proposed by Durigon et al. (2014) as shown in Equation 5.

$C_{N D V I}=\frac{-N D V I+1}{2}$

where $\mathrm{C}_{\mathrm{NDVI}}$ is the dimensionless soil cover factor. NDVI is a widely used indicator of vegetation health and ranges from -1 to +1 , with higher values attributed to areas of higher plant density. The index was obtained using Equation 6 (Tucker, 1979):

$N D V I=\frac{N I R-R E D}{N I R=R E D}$

where NIR and RED are the near and red infrared spectral bands, respectively. The NDVI was calculated from the Landsat-8 OLI images used in the subbasin land use mapping, as previously described. To improve the representability of NDVI in the subbasin, we used the $\mathrm{C}_{\mathrm{NDVI}}$ factor average value obtained between June 2018 and July 2019.

The $\mathrm{P}$ factor value expresses the impact of soil conservation practices on erosion rates and ranges from 0 to 1 , where values close to 0 indicate comprehensive soil conservation practices. We assign the $\mathrm{P}$ factor values based on the management practices adopted in the subbasin and on conducted field surveys (Bertoni; Lombardi Neto, 2012). The $P$ factor attributed to coffee was 0.5 due to the planting along the contour lines and the maintenance of spontaneous vegetation between the coffee lines. In the areas with cultivation of maize under conventional systems, uneven eucalyptus planting, and access roads with exposed soil, we attributed a $P$ factor of 1 , while a $P$ factor of 0.01 was attributed to forests.
ArcMap 10.3 software (ESRI, 2015) was used in the processing and modeling steps and to convert the parameters to a raster data format. Each pixel of the soil loss maps based on $\mathrm{C}_{\text {lit }}$ and $\mathrm{C}_{\mathrm{NDVI}}$ was converted into 46.000 points using the ArcGIS 10.3 Raster to Point tool. Data of the $\mathrm{C}_{\mathrm{NDVI}}$ factor $(\mathrm{X})$ were plotted against the $\mathrm{C}_{\text {lit }}$ factor $(\mathrm{Y})$, and a linear relationship was fitted to assess the deviation from a 1:1 slope.

\section{Validation}

Soil loss estimated by RUSLE includes both the soil fraction retained along the area and the fraction that reaches the water bodies (net erosion). Consequently, the integration of the model with the sediment delivery ratio (SDR) is necessary to determine the net erosion. The methodology proposed by Gavrilovic (1962) (Equation 7) was used to calculate the SDR because of the satisfactory result obtained in our previous study (Lense et al., 2019) in the same subbasin.

$S D R=\frac{(O \cdot D)^{0.5}}{0.25 \cdot(L+10)}$

where $\mathrm{O}$ is the subbasin perimeter $(9.28 \mathrm{~km}), \mathrm{D}$ is the mean elevation difference $(0.06 \mathrm{~km})$, obtained by the difference between the mean altitude $(861 \mathrm{~m})$ and the minimum altitude $(795 \mathrm{~m})$, and $\mathrm{L}$ is the length of the subbasin measured from the watercourses $(3.32 \mathrm{~km})$.

The model validation was realized by combining RUSLE with the SDR to calculate the net erosion in the subbasin area. Thus, the results were compared to the annual sediment transported according to Beskow et al. (2009). We used total solids data monitored between 2001 and 2018 by a hydrosedimentological station operated by the Minas Gerais Institute of Water Resources Management (IGAM), located at coordinates $45^{\circ} 53^{\prime} 35^{\prime \prime}$ $\mathrm{W}$ and $21^{\circ} 39^{\prime} 55^{\prime \prime} \mathrm{S}$ ).

A curve relating the total sediment transported in the subbasin and the water discharge (Figure 2) was plotted to determine the annual sediment transport, in relation to the flow versus sediment curve and the daily runoff data from 2018 obtained from the National Water Agency (Agência Nacional de Águas - ANA, 2019).

\section{RESULTS AND DISCUSSION}

The subbasin soils exhibited the following characteristics: granular structure with a moderate degree and medium size, slight plastic consistency, and a basic 
hue of 2.5 YR. The clay content ranged from $41 \%$ to $59 \%$ (clayey texture). The $\mathrm{K}$ factor parameters are presented in Table 1. These characteristics provide a soil erodibility of $0.020 \mathrm{Mg} \mathrm{h} \mathrm{MJ}^{-1} \mathrm{~mm}^{-1}$ for the subbasin Latosols, which were close to those found by Mendes Júnior et al. (2018) (0.040 to $0.026 \mathrm{Mg} \mathrm{h} \mathrm{MJ}^{-1} \mathrm{~mm}^{-1}$ ) and Silva et al. (1999) (0.002 to $0.034 \mathrm{Mg} \mathrm{h} \mathrm{MJ}^{-1} \mathrm{~mm}^{-1}$ ).

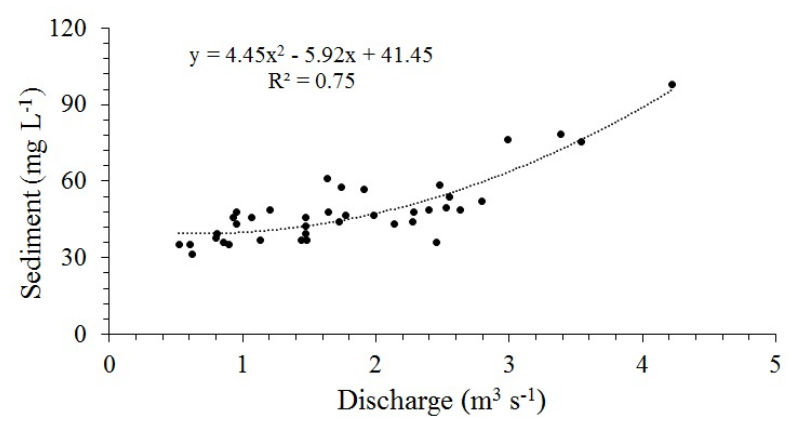

Figure 2: Water discharge curve (transported sediment versus water flow) of the Coroado Stream subbasin, Alfenas, Minas Gerais, Brazil.

We observed a high $\mathrm{R}$ factor according to the Foster et al. (1981) classification, ranging from 6,730 to 7,769 MJ mm $\mathrm{ha}^{-1} \mathrm{~h}^{-1}$ year $^{-1}$ (Figure $3 \mathrm{~A}$ ), which can be explained by the high rainfall intensity in the area $(1,500 \mathrm{~mm})$. These results are close to those found by Aquino et al. (2012) for the same region, which found a range of 5,145 to 7,776 $\mathrm{MJ} \mathrm{mm} \mathrm{ha}{ }^{-1} \mathrm{~h}^{-1}$ year-1, indicating a good accuracy for the erosivity factor calculated by Mello et al. (2013) in the Coroado Stream subbasin.

The LS factor presents an average of 4.3, and only $11 \%$ of the subbasin showed values higher than 10 , which indicates that these areas are more vulnerable to soil erosion (Beskow et al., 2009; Oliveira et al., 2014). Vulnerable areas were mainly concentrated in high-slope places with a higher runoff velocity process (Beskow et al., 2009; Rodrigues et al., 2017). The highest values of the LS factor are spatially distributed throughout the subbasin(Figure 3B), reinforcing the need for extensive management to reduce erosion. Similar results were observed by Oliveira et al. (2014) and Steinmetz et al. (2018), who analyzed the water erosion in southeastern and southern Brazil, respectively.

The $\mathrm{C}_{\mathrm{NDVI}}$ factor reflected the effect of vegetal cover density on the soil surface, indicating more comprehensive soil protection. Thus, we found lower $\mathrm{C}_{\mathrm{NDVI}}$ factor values in areas with higher soil protection, such as eucalyptus, native, and advanced stages of forests (Figure 3C). Areas with exposed soil such as access roads, early stages of forests, and maize cultivated under the conventional system present higher $\mathrm{C}$ factor values and, consequently, higher erosion rates. The $\mathrm{C}_{\text {lit }}$ factor values are presented in Table 2 .

Table 1: Values of the variables involved in the indirect calculation of soil erodibility (K).

\begin{tabular}{|c|c|c|}
\hline Variable & Description & Value \\
\hline $\mathrm{K}$ & Erodibility (Mg h MJ $\left.{ }^{-1} \mathrm{~mm}^{-1}\right)$ & 0.02 \\
\hline$* X_{14}$ & Code of the hue of the moist soil according to Munsell (dimensionless) & 2.00 \\
\hline$\star X_{16}$ & Structure degree code (dimensionless) & 2.00 \\
\hline$* X_{17}$ & Structure size code (dimensionless) & 3.00 \\
\hline$* X_{18}$ & Structure shape code (dimensionless) & 3.00 \\
\hline$* X_{19}$ & Soil plasticity code (dimensionless & 2.00 \\
\hline$x_{22}$ & Fine sand content dispersed in $\mathrm{NaOH} 0.1 \mathrm{~mol} \mathrm{~L}^{-1}\left(\mathrm{~g} \mathrm{~kg}^{-1}\right)$ & 96.00 \\
\hline$x_{23}$ & Very fine sand content dispersed in $\mathrm{NaOH} 0.1 \mathrm{~mol} \mathrm{~L}^{-1}\left(\mathrm{~g} \mathrm{~kg}^{-1}\right)$ & 27.30 \\
\hline$x_{24}$ & Silt content dispersed in $\mathrm{NaOH} 0.1 \mathrm{~mol} \mathrm{~L}^{-1}\left(\mathrm{~g} \mathrm{~kg}^{-1}\right)$ & 102.00 \\
\hline$x_{25}$ & Clay content dispersed in $\mathrm{NaOH} 0.1 \mathrm{~mol} \mathrm{~L}^{-1}\left(\mathrm{~g} \mathrm{~kg}^{-1}\right)$ & 597.00 \\
\hline$X_{26}$ & Very coarse sand content dispersed in water $\left(\mathrm{g} \mathrm{kg}^{-1}\right)$ & 26.25 \\
\hline$x_{27}$ & Coarse sand content dispersed in water $\left(\mathrm{g} \mathrm{kg}^{-1}\right)$ & 79.00 \\
\hline$X_{31}$ & Silt content dispersed in water $\left(\mathrm{g} \mathrm{kg}^{-1}\right)$ & 169.50 \\
\hline$x_{32}$ & Clay content dispersed in water $\left(\mathrm{g} \mathrm{kg}^{-1}\right)$ & 421.80 \\
\hline$x_{34}$ & Flocculation index (dimensionless) & 293.00 \\
\hline
\end{tabular}

*Parameters coded as Silva et al. (1999). 

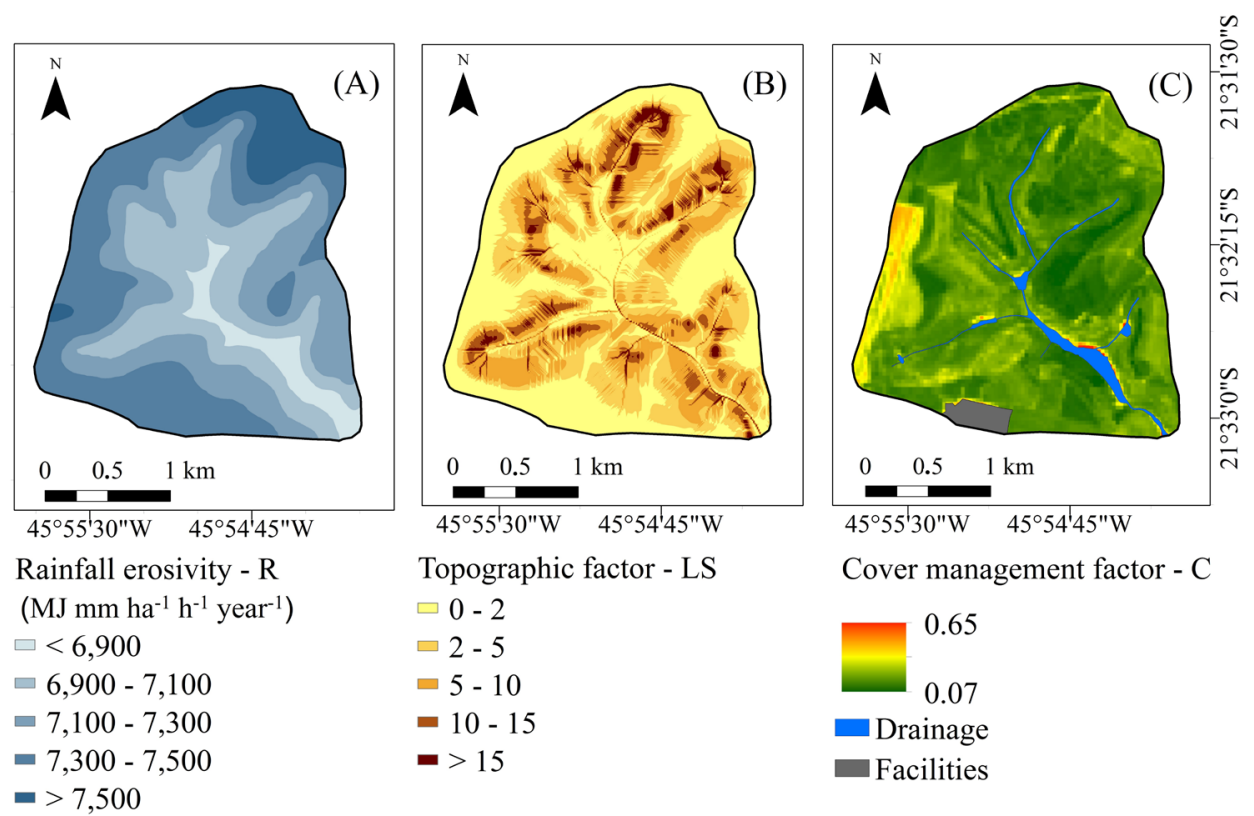

Cover management factor - C

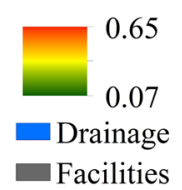

Figure 3: Spatial distribution of Erosivity - R (A), Topographic factor - LS (B), and Cover and management factor (C).

Table 2: Cover and management factor values obtained from the specialized literature.

\begin{tabular}{cc}
\hline $\begin{array}{c}\text { Land use and } \\
\text { occupation classes }\end{array}$ & $C_{\text {lit }}$ \\
\hline Coffee & 0.0866 (Prochnow et al., 2005) \\
Forest & 0.0150 (Silva et al., 2016) \\
Maize & 0.0827 (Silva et al., 2010) \\
Eucalyptus & 0.1240 (Silva et al., 2016) \\
Sugarcane & 0.1124 (Silva et al., 2010) \\
Pasture & 0.0500 (Silva et al., 2010) \\
Access roads & 1.0000 (Mendes Júnior et al., 2018) \\
\hline
\end{tabular}

Notes: $C_{\text {lit }}=\mathrm{C}$ factor based on the literature data.

RUSLE estimated the total soil loss at $11,235.54$ and $11,670.00 \mathrm{Mg}$ year ${ }^{-1}$ based on the $\mathrm{C}_{\text {lit }}$ and $\mathrm{C}_{\mathrm{NDVI}}$ values, respectively. The SDR in the subbasin was 0.118 , indicating that $11.8 \%$ of the eroded soil volume reaches water bodies contributing to siltation and water quality depreciation. This soil fraction corresponds to a net erosion of 1,280.85 and 1,377.02 $\mathrm{Mg}$ year $^{-1}$ with averages of 2.40 and $2.59 \mathrm{Mg} \mathrm{ha}^{-1}$ year ${ }^{-1}$ based on $\mathrm{C}_{\text {lit }}$ and $\mathrm{C}_{\mathrm{NDVI}}$, respectively.

Both methods presented the highest rates of net erosion $\left(>10.0 \mathrm{Mg} \mathrm{ha}^{-1}\right.$ year $\left.^{-1}\right)$ in highly vulnerable sites based on the LS factor values (Figure 4). We found that using the $\mathrm{C}_{\text {lit }}$ factor, $82 \%$ of the subbasin area presents low-intensity erosion $\left(<2.5 \mathrm{Mg} \mathrm{ha}^{-1}\right.$ year $\left.^{-1}\right)$ (Figure 4A), according to the classification by Beskow et al. (2009). However, using the $\mathrm{C}_{\mathrm{NDVI}}$ factor, this ratio dropped to $66 \%$ (Figure 4B).

The sediment generation calculated based on the IGAM hydrosedimentological station was $3.04 \mathrm{Mg} \mathrm{ha}^{-1}$ year-1 ${ }^{-1}$ Comparing this value with the results, RUSLE underestimated soil losses by $0.64 \mathrm{Mg} \mathrm{ha}^{-1}$ year ${ }^{-1}$ using $\mathrm{C}_{\text {lit }}$ and $0.45 \mathrm{Mg} \mathrm{ha}^{-1}$ year ${ }^{-1}$ with $\mathrm{C}_{\mathrm{NDV}}$, which corresponds to errors of $21.05 \%$ and $14.80 \%$, respectively. According to Pandey, Chowdary and Mal (2007), errors smaller than $20 \%$ are considered tolerable. Therefore, only $\mathrm{C}_{\mathrm{NDVI}}$ based estimates could be validated for the Coroado Stream subbasin. Almagro et al. (2019) obtained a similar result with errors of $13 \%$ using $\mathrm{C}_{\mathrm{NDVI}}$ and $20 \%$ using $\mathrm{C}_{\text {lit? }}$, demonstrating the higher efficiency of the $\mathrm{C}_{\mathrm{NDVI}}$ factor compared to the traditional method.

In addition to the more accurate results, another advantage of the approach is the use of remote sensing data, which allows the vegetation cover to be estimated anywhere with satellite coverage. There is a lack of $\mathrm{C}$ factor values in the literature. In contrast, satellite images with an adequate spatiotemporal resolution for the erosion model are available free throughout the Brazilian territory through the Imaging Division (INPE, 2019), making it possible to estimate the $\mathrm{C}$ factor and soil loss at different scales (Almagro et al., 2019). 

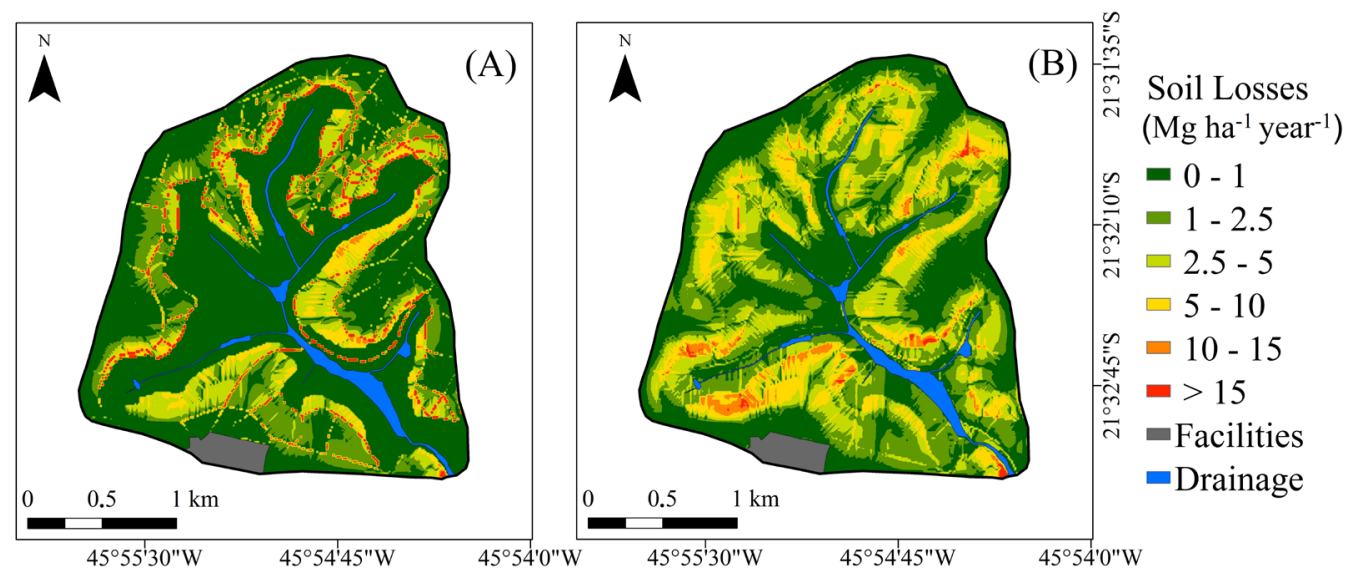

Figure 4: Map of the spatial distribution of soil losses based on $C_{\text {lit }}(A)$ and $C_{N D V I}(B)$ factors in the Coroado Stream subbasin, Alfenas, southern Minas Gerais, Brazil. Notes: $\mathrm{C}_{\text {lit }}=\mathrm{C}$ factor based on literature data; $\mathrm{C}_{\mathrm{NDVI}}=\mathrm{C}$ factor based on NDVI data.

Considering the land use and occupation classes, we found different erosion rates by the different $\mathrm{C}$ factor calculation approaches (Table 3).

Table 3: Land use and occupation classes and erosion rates estimated by the Revised Universal Soil Loss Equation in the Coroado Stream subbasin, Alfenas, Minas Gerais, Brazil.

\begin{tabular}{ccc}
\hline \multirow{2}{*}{ Soil use and occupation class Soil loses $\mathrm{Mg} \mathrm{ha}^{-1}$ year $^{-1}$} \\
\cline { 2 - 3 } & $\mathrm{C}_{\text {lit }}$ & $\mathrm{C}_{\mathrm{NDV}}$ \\
\hline Coffee & 2.17 & 2.18 \\
Forest & 1.70 & 0.60 \\
Maize & 4.50 & 2.12 \\
Eucalyptus & 4.95 & 5.53 \\
Sugarcane & 2.60 & 1.70 \\
Access roads & 5.20 & 18.67 \\
\hline
\end{tabular}

Notes: $C_{\text {lit }}=C$ factor based on literature data; $C_{\mathrm{NDVl}}=\mathrm{C}$ factor based on NDVI data.

The $\mathrm{C}_{\mathrm{NDVI}}$ factor is calculated cell by cell in a GIS, which enables a more representative result of the heterogeneity of vegetation cover in the area. Based on the deviation from a 1:1 relationship, we found that, in general, the $\mathrm{C}_{\text {lit }}$ factor overestimates the soil loss estimates compared to those using the $\mathrm{C}_{\mathrm{NDVI}}$ factor (Figure 5). The clearest example of this overestimation is that the lowest soil loss value calculated for the access roads by the $\mathrm{C}_{\mathrm{NDVI}}$ factor is $5.20 \mathrm{Mg} \mathrm{ha}^{-1}$ year $^{-1}$ while the corresponding $\mathrm{C}_{\text {lit }}$ factor is $18.67 \mathrm{Mg} \mathrm{ha}^{-1}$ year $^{-1}$.

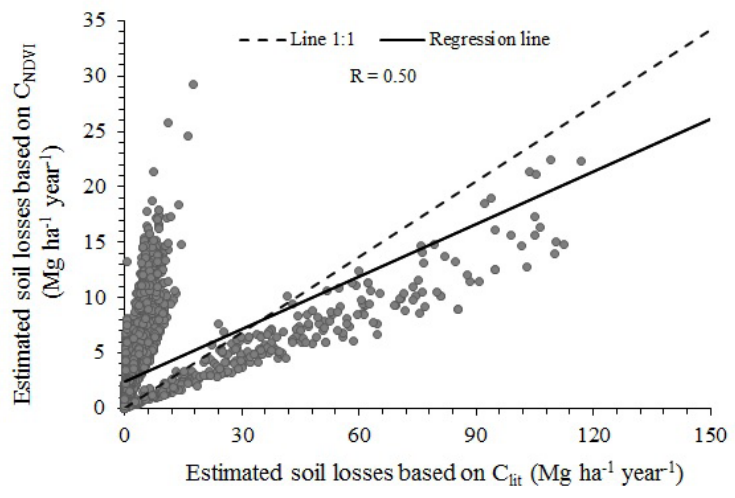

Figure 5: Comparison between soil losses based on $C_{\text {lit }}(A)$ and $C_{\text {NDVI }}$ (B) factors in the Coroado Stream subbasin, Alfenas, southern Minas Gerais, Brazil. Notes: $C_{\text {lit }}=C$ factor based on the literature data; $C_{\text {NDVI }}$ = C factor based on NDVI data.

The $\mathrm{C}_{\text {lit }}$ factor considered the static value of 1 for the access roads, representing the absence of vegetation in these areas, which increases the soil loss rates. However, the access roads in coffee often have low agricultural machinery traffic and are occupied by spontaneous vegetation or grass growth, which was observed in the Coroado Stream subbasin (Figure 6). Consequently, the $\mathrm{C}_{\mathrm{NDVI}}$ factor results are closer to the actual subbasin vegetation cover. In the case of access roads, the vegetation present in the area can mitigate the soil erosion process resulting in low soil loss estimates. Moreover, the $\mathrm{C}_{\mathrm{NDVI}}$ factor can provide a better vegetation cover estimation in forested areas in different stages of regeneration, which provide distinct levels of soil protection. 

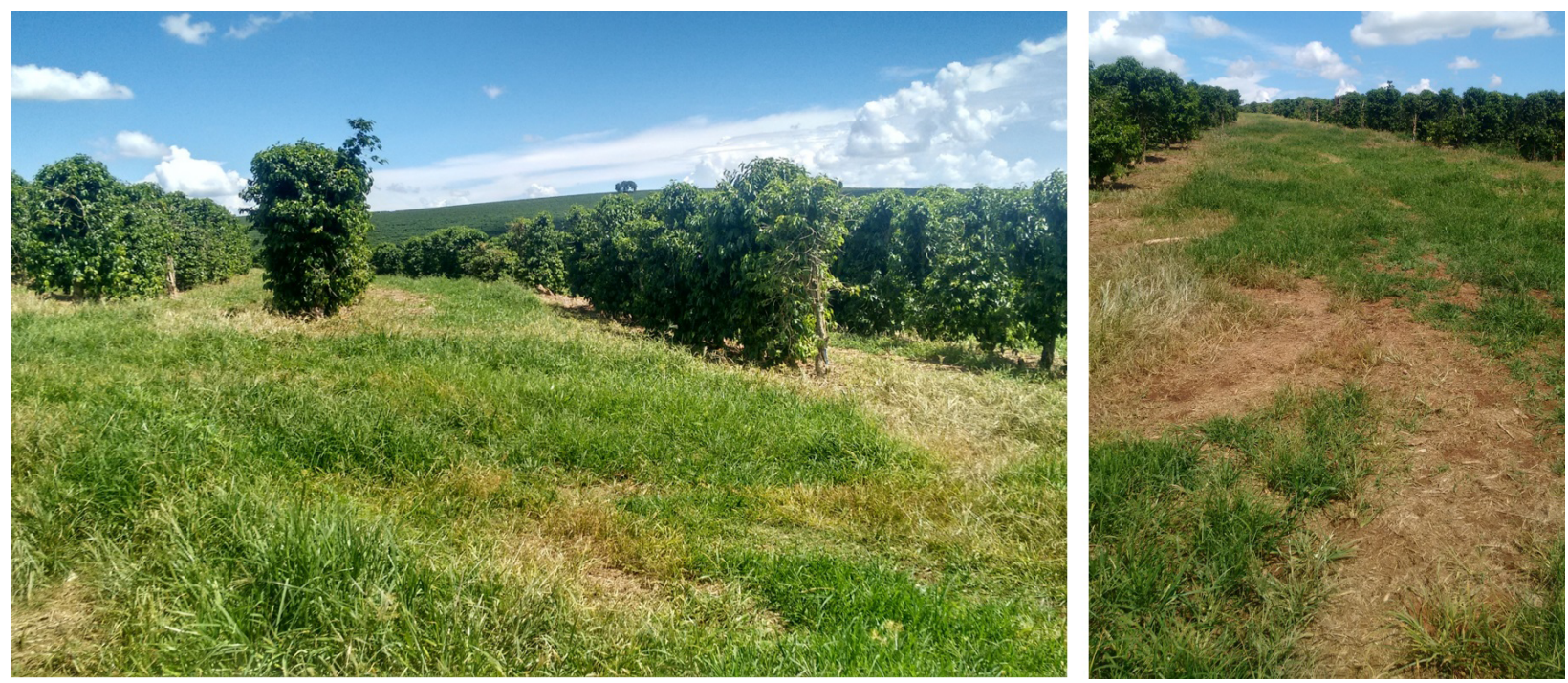

Figure 6: Access roads in the coffee areas of the Coroado Stream subbasin, Municipality of Alfenas, southern Minas Gerais, Brazil.

Regardless of the methodology used to determine the $\mathrm{C}$ factor, the RUSLE results indicated high soil losses in some subbasin areas (Figure 3). Some alternatives to reduce water erosion would be the introduction of practices that improve soil cover in the areas of maize and sugarcane, such as the adoption of no-till systems and the management of plant residues. Terracing in the eucalyptus areas under uneven planting and the construction of containment basins around the access roads located on steep reliefs could also help to control the erosive process (Bertoni; Lombardi Neto, 2012; Mendes Júnior et al., 2018).

Additionally, to reduce soil losses to a minimum rate along the subbasin area, the conservation practices already in place should be maintained and intensified to ensure the long-term sustainability of agricultural production.

The subbasin presented high erosivity, constant erodibility, and steep slopes distributed throughout the area. Consequently, vegetation cover and soil management ( $\mathrm{C}$ and $\mathrm{P}$ factors) are the main factors responsible for the variations in water erosion, especially in the places where LS factor indicated high vulnerability to the erosive process.

\section{CONCLUSIONS}

Soil loss estimates generated by RUSLE based on the determination of the $\mathrm{C}$ factor from NDVI were more accurate than the results based on the $\mathrm{C}$ factor obtained from the literature data, with errors of $14 \%$ and $21 \%$, respectively. However, both methodologies indicated that the Coroado Stream subbasin represents areas with high erosion rates, where the adoption of mitigation measures for water erosion should be prioritized.

\section{ACKNOWLEDGEMENTS}

The authors thank the Fundação de Amparo à Pesquisa do Estado de Minas Gerais (FAPEMIG) for the scholarship offered to the first author. Ipanema Agrícola S. A. is gratefully acknowledged for funding the research and conceding the study area. This study was funded in part by the Coordenação de Aperfeiçoamento de Pessoal de Nível Superior - Brasil (CAPES) Finance Code 001.

\section{REFERENCES}

AGÊNCIA NACIONAL DE ÁGUAS - ANA. Sistema Nacional de Informações sobre Recursos Hídricos (SNIRH). Ministério do Meio Ambiente, 2019. Available in: <https://www.snirh. gov.br/hidroweb/publico/apresentacao.jsf>. Access in: December, 10, 2019.

ALMAGRO, A. et al. Improving cover and management factor (C-factor) estimation using remote sensing approaches for tropical regions. International Soil and Water Conservation Research, 7(4):325-334, 2019. 
ALVARES, C. A. et al. Köppen's climate classification map for Brazil. Meteorologische Zeitschrift, 22(6):711-728, 2013.

ANH, P. T. Q. et al. Linkages among land use, macronutrient levels, and soil erosion in northern Vietnam: A plot-scale study. Geoderma, 234(1):352-362, 2014.

AQUINO, R. F. et al. Spatial variability of the rainfall erosivity in southern region of Minas Gerais state, Brazil. Ciência e Agrotecnologia, 36(5):533-542, 2012.

BERTONI, J.; LOMBARDI NETO, F. Conservação do solo. $3^{\circ}$ edição, São Paulo: Ícone, 2012. 360p.

BESKOW, S. et al. Soil erosion prediction in the Grande River Basin, Brazil using distributed modeling. Catena, 79(1):4959, 2009.

CHEN, T. et al. Regional soil erosion risk mapping using RUSLE, GIS, and remote sensing: A case study in Miyun Watershed, North China. Environmental Earth Sciences, 63(3):533$541,2011$.

CUNHA, E. R.; BACANI, V. M.; PANACHUKI, E. Modeling soil erosion using RUSLE and GIS in a watershed occupied by rural settlement in the Brazilian Cerrado. Natural Hazards, 85(2):851-868, 2017.

DEVÁTÝ, J. et al. Effects of historical land use and land pattern changes on soil erosion - Case studies from Lower Austria and Central Bohemia. Land Use Policy, 82(1):674-685, 2019.

DURIGON, V. L. et al. NDVI time series for monitoring RUSLE cover management factor in a tropical watershed. International Journal of Remote Sensing, 35(2):441453, 2014.

EMPRESA BRASILEIRA DE PESQUISA AGROPECUÁRIA EMBRAPA. Manual de métodos de análise do solo. 3. ed. rev. Brasília: Embrapa, 2017. 577p.

ENVIRONMENTAL SYSTEMS RESEARCH INSTITUTE - INC - ESRI. ARCGIS Professional GIS for the desktop version 10.3. Redlands, Califórnia, EUA, Software, 2015. Available in: <http://desktop.arcgis.com/en/arcmap/10.3/get-started/ quick-start-guides/arcgis-desktop quick-start-guide.htm>. Access in: December, 10, 2019.

FOSTER, G. R. et al. Conversion of the universal soil loss equation to SI metric units. Journal of Soil and Water Conservation, 36(6):355-359, 1981.

GANASRI, B. P.; RAMESH, H. Assessment of soil erosion by RUSLE model using remote sensing and GIS - A case study of Nethravathi Basin. Geoscience Frontiers, 7(6):953-961, 2016.
GAVRILOVIC, S. A method for estimating the average annual quantity of sediments according to the potency of erosion. Bulletin of the Faculty of Forestry, 26(1):151168, 1962.

GEE, G. W.; BAUDER, J. W. Particle-size analysis. In: KLUTE, A. Methods of soil analysis: physical and mineralogical methods. 2. ed. Madison: American Society of Agronomy, 1986. v.1, p.383-411.

HAIDARA, T. et al. Efficiency of Fuzzy Analytic Hierarchy Process to detect soil erosion vulnerability. Geoderma, 354(1):113853, 2019.

IMAMOGLU, A.; DENGIZ, O. Determination of soil erosion risk using RUSLE model and soil organic carbon loss in Alaca catchment (Central Black Sea region, Turkey). Rendiconti Lincei, 28(1):11-23, 2017.

INFRAESTRUTURA DE DADOS ESPACIAIS DO SISTEMA ESTADUAL DE MEIO AMBIENTE E RECURSOS HÍDRICOS - SISEMA. Curvas de nível do Estado de Minas Gerais. Belo Horizonte: IDE Sisema, 2019. Available in: <http:// idesisema.meioambiente.mg.gov.br.>. Access in: December, 10, 2019.

INSTITUTO NACIONAL DE METEOROLOGIA - INMET. Estações pluviométricas convencionais. Ministério da Agricultura, Pecuária e Abastecimento (MAPA), 2019. Available in: <http://www.inmet.gov.br/portal/index.php?r=bdmep/ bdmep>. Access in: December, 10, 2019.

INSTITUTO NACIONAL DE PESQUISAS ESPACIAIS - INPE. Divisão de Geração de Imagens (DIDGI). Ministério da Ciência, Tecnologia, Inovações e Comunicações, 2019. Available in: <http://www.dgi.inpe.br/catalogo/>. Access in: December, 10, 2019.

LENSE, G. H. E. et al. Estimates of soil losses by the erosion potential method in tropical latosols. Ciência e Agrotecnologia, 43:e012719, 2019.

MELLO, C. R. et al. Multivariate models for annual rainfall erosivity in Brazil. Geoderma, 203(1):88-102, 2013.

MENDES JÚNIOR, $\mathrm{H}$. et al. Water Erosion in Oxisols under Coffee Cultivation. Revista Brasileira de Ciência do Solo, 42(1):1-14, 2018

MOORE, I. D.; BURCH, G. J. Physical basis of the length slope factor in the Universal Soil Loss Equation. Soil Science Society of America, 50(5):1294-1298, 1986.

NEARING, M. A. et al. Modeling response of soil erosion and runoff to changes in precipitation and cover. Catena, 61(2):131-154, 2005. 
OLIVEIRA, V. A. et al. Soil erosion vulnerability in the Verde River Basin, southern Minas Gerais. Ciência e Agrotecnologia, 38(3):262 269, 2014.

OUYANG, W. et al. Soil erosion dynamics response to landscape pattern. Science of The Total Environment, 408(6):13581366, 2010.

PANAGOS, P.; KATSOYIANNIS, A. Soil erosion modelling: The new challenges as the result of policy developments in Europe. Environmental Research, 172(1):470-474, 2019.

PANDEY, A.; CHOWDARY, V. M.; MAL, B. C. Identification of critical erosion prone areas in the small agricultural watershed using USLE, GIS and remote sensing. Water Resources Management, 21(4):729-746, 2007.

PRASANNAKUMAR, V. et al. Estimation of soil erosion risk within a small mountainous sub-watershed in Kerala, India, using Revised Universal Soil Loss Equation (RUSLE) and geo-information technology. Geoscience Frontiers, 3(2):209-215, 2012.

PROCHNOW, D. et al. Razão de perdas de terra e fator C da cultura do cafeeiro em cinco espaçamentos, em Pindorama (SP). Revista Brasileira de Ciência do Solo, 29(1):91-98, 2005.

RENARD, K. G. et al. Predicting soil erosion by water: A guide to conservation planning with the Revised Universal Soil Loss Equation (RUSLE). Washington: United States Department of Agriculture, 1997. 384p.

RODRIGUES, J. A. M. et al. Estimativa da vulnerabilidade dos solos à erosão hídrica na bacia hidrográfica do Rio Cervo - MG. Geociências, 36(3):531-542, 2017.

SILVA, B. P. C. et al. Soil and water losses in eucalyptus plantation and natural forest and determination of the
USLE factors at a pilot sub-basin in Rio Grande do Sul, Brazil. Ciência e Agrotecnologia, 40(4):432-442, 2016.

SILVA, D. C. C. et al. Identificação de áreas com perda de solo acima do tolerável usando NDVI para o cálculo do fator C da USLE. Raega - 0 Espaço Geográfico em Análise, 42(1):72-85, 2017.

SILVA, F. G. B. et al. Previsão da perda de solo na Fazenda Canchim - SP (EMBRAPA) utilizando geoprocessamento e o USLE 2D. Engenharia Sanitária e Ambiental, 15(2):141$148,2010$.

SILVA, M. L. N. et al. Proposição de modelos para estimativa da erodibilidade de Latossolos brasileiros. Pesquisa Agropecuária Brasileira, 34(12):22879228, 1999.

STEINMETZ, A. A. et al. Assessment of soil loss vulnerability in data-scarce watersheds in southern Brazil. Ciência e Agrotecnologia, 42(6):575-587, 2018.

SUN, W. et al. Assessing the effects of land use and topography on soil erosion on the Loess Plateau in China. Catena, 21(1):151-163, 2014.

TAVARES, A. S. et al. Modeling of water erosion by the erosion potential method in a pilot subbasin in southern Minas Gerais. Semina: Ciências Agrárias, 40(2):555572, 2019.

TUCKER, C. J. Red and photographic infrared linear combination for monitoring vegetation. Remote Sensing of Environment, 8(2):127-150, 1979.

WISCHMEIER, W. H; SMITH, D. D. Predicting rainfall erosion losses. A guide to conservation planning. 1.ed. Washington: United States Department of Agriculture. Supersedes Agriculture Handbook. 1978. 58p. 